UDC 168+001.89]:3

\title{
METHODOLOGY AND ORGANIZATION OF SCIENTIFIC RESEARCHES IN THE FIELD OF SOCIAL-HUMANITARIAN AND BEHAVIOURAL SCIENCES
}

\author{
(C) Bojko, Elena \\ Zaporizhzhia State Engineering Academy (Zaporizhzhia, Ukraine) \\ E-mail: lvbojko@yahoo.com, ORCID 0000-0003-0719-8921 \\ (C) Voronkova, Valentyna \\ Zaporizhzhia State Engineering Academy (Zaporizhzhia, Ukraine) \\ E-mail: valentinavoronkova236@gmail.com, ORCID: 0000-0003-4361-1701 \\ (C) Nikitenko, Vitalina \\ Zaporizhzhia State Engineering Academy (Zaporizhzhia, Ukraine) \\ E-mail: vitalina2006@ukr.net, ORCID 0000-0001-9588-7836
}

\begin{abstract}
The urgency of the study lies in the fact that modern socio-economic development is characterized by a constant updating of the system of scientific knowledge, an intensive increase in the number and complexity of information. In these conditions, the task of highly qualified specialists, who on a qualitatively new theoretical and methodological basis, can analyze the complexities of the modern world deeply and systematically, make optimal solutions for society as a whole and for the economy, in particular rises as the main task of high school. The central problem is the study of methods and approaches of scientific knowledge, through which one can deeply penetrate into the essence of the investigated phenomena and processes of objective reality. The objectives of the study are to analyze a set of methods and approaches that, in their totality, constitute a methodology and organization of scientific research and are useful for social sciences and humanities and behavioral sciences. Methodology - (grammatical methods - method, method and logo - science, knowledge) - the doctrine of the rules of thinking in the creation of the theory of science. The methodology is considered as a doctrine of the scientific method of cognition or as a system of scientific principles, on the basis of which the research is based and the choice of a set of cognitive means, methods and means of research is carried out. The result of the study. Philosophical methodology carries out two types of functions: 1) reveals the meaning of scientific activity and its interrelation with other spheres of activity, that is, examines science in relation to practice, society, human culture; 2) solves the problem of improvement, optimization of scientific activity, going beyond the limits of philosophy, although based on the ideological and general methodological guidelines developed by it. Methodology is a conceptual statement of the purpose, content, research methods, which provide the obtaining of the most objective, accurate, systematic information about the processes and phenomena being investigated. Conclusions. The methodology and organization of scientific researches investigates the regularities of the functioning and development of science, the structure and dynamics of scientific knowledge, deep penetration into the essence of the investigated phenomena and processes. Key words: method, methodology, approach, technology, methodology, scientific knowledge, philosophical methodology.
\end{abstract}

Relevance of research. One of the key means to ensure success in the training of competitive professionals is the qualitatively new mastery of students in social, humanitarian and behavioral disciplines. And this is impossible without mastering the fundamental principles of the methodology of scientific research. For the researcher, it is important not only to establish new facts and the ability to give them an explanation, to disclose their cognitive, theoretical and practical significance. The accumulation of scientific facts in the process of research of social-humanitarian and behavioral sciences is a creative process based on the idea of a scientist, an idea as a product of thinking, a form of reflection of reality, an object of study, an awareness of the purpose, the prospect of knowledge and the practical transformation of reality. The results of new ideas may diverge from the generally accepted provisions of science - paradigms. The acquisition of new knowledge takes place according to the scheme: paradigm - paradox - a new paradigm. The development of science is a change in paradigms, methods, stereotypes of thinking, which is based on the methodology and needs its development [1].

\section{(C) Bojko Elena,Voronkova Valentyna, Nikitenko Vìtalina, 2018}


Methodology - a set of methods and techniques aimed at studying contemporary society. Distinguish fundamental, general scientific principles, which are their own methodology, the specific scientific principles underlying the theory of a discipline or scientific field, and the system of specific methods and techniques used to solve special research tasks. The methodology performs the following functions: defines methods for acquiring scientific knowledge that reflect dynamic processes and phenomena; directs, envisages a special way on which a certain scientific research goal is achieved; provides comprehensive information about the process or phenomenon being studied; Helps to introduce new information into the science of science fund; provides clarification, enrichment, systematization of terms and concepts in science; creates a system of scientific information, which is based on objective facts, and is a logical-analytical tool for scientific knowledge [2].

Research results. Method (gr. Methodos) a way of knowing, studying the phenomena of nature and social life of social-humanitarian and behavioral sciences; it is a collection of techniques or operations of practical or theoretical development of reality, subordinated to the solution of a specific task. The difference between the method and the theory has a functional character: formed as the theoretical result of the previous study, the method serves as the starting point and condition for future research.

In the most general sense, the method is a way, a way of achieving the goal and objectives of the study. It answers the question: how to know. The concept of "method" is defined as a set of united single research technology principles that are used in solving specific research tasks. The method and technology are closely interrelated. The method gives a general direction, the general principle of the organization of the study procedure, while the technology is a set of separate operations that provide the implementation of research tasks. Strategic methodological provisions find their practical implementation in research methods.

The method of scientific research - a set of united by a single general principle of the investigated technologies, which are used to solve specific research problems. The method is the way a phenomenon, phenomenon or process is investigated in any field of activity. The choice of the method of research is entirely determined by the content of the problem under study, which is a contradiction between the knowledge and the unidentified in the structure of scientific knowledge. Unidentified cannot be represented by consciousness because of the knowledge that is not yet available and which still needs to be known, which is an indication that the existing knowledge should be supplemented, developed and modified [3].

In order to cover the sphere unknown to any previous knowledge, various scientific assumptions are made, scientific hypotheses are formed. The scientific hypothesis is a scientifically substantiated proposition that asks for the direction of scientific research, the search for questions on previously asked questions that arose during the analysis and comprehension of the problem under study. Scientific hypothesis or a set of some scientific hypotheses is an intermediate link between knowledge and ignorance. The precise formulation of the scientific hypothesis preceded any scientific research, the choice of method, which primarily involves the possibility of solving the problem, answering the questions posed.

The method, therefore, appears to us as the main working tool, designed to ensure the partial or complete acceptance of the hypotheses initiated at the beginning of the study. The study of the problem ultimately and exclusively from the formulation, verification or rejection of hypotheses and their transformation into new knowledge, directly depends on the methodology chosen and the specific method. The right choice of a scientific method is an important, but, at times, decisive stage of any scientific research, including managerial. The method is a theoretically meaningful and logically justified method of cognitive activity in order to obtain reliable knowledge about the object of study; totality, or rather - a system of theoretical generalizations, rules (principles) and methods of scientific and cognitive activity, which provides the emergence of new reliable knowledge, and is the actual methodology [4].

\section{Methods and techniques of research}

In the theoretical and methodological aspect of the study of contemporary society, it was decided to distinguish between the concept of "approach", "method", "methodology", "technology", "methodics".

Approach - 1) informational - based on the information principle, according to which virtually all phenomena and processes have an

Methodology and organization of scientific researches in the field of social-humanitarian and behavioural sciences 
information basis and are interrelated information nature; 2) cultural (axiological) as a component of the process of formation of information culture; 3) a synergistic approach associated with the self-organization of the information society [5].

The method is a morphological way of studying the problems of the information society - digital divide, zombifying of society, information wars in business and politics, computer crime (cybercrime), information danger, adaptation of a person to life in an information society.

Methodology - a system of rules, the use of methods, techniques and operations associated with the formation of a global information society. The technique is the technology itself, which can be used differently and used in the study in accordance with relevant and developed techniques. If the method in its nature is conceptual, is the result of scientific research and is created as a special scientific achievement, so related to the new theoretical knowledge, corresponds to a certain understanding of the content and forms of research activities, then the technologies and techniques used in the study procedure are not serious theoretical and methodological load [6].

Methodology (gr. Methodike) - a set of methods, methods of conducting scientific research, a system of rules for the use of methods, techniques and operations.

Technology is a set of previously learned operations that define a specific action (often with the use of social tools and instruments) to conduct research. Technology - the introduction of information technology as knowledge management and the formation of information competence of the individual in the context of modern social transformations.

The method may consist of several sequentially arranged or parallel technologies that provide the result of the study. In this case, technologies do not represent once and for all the established order or sequence of procedures: with each new research technology is changing, enriched, adjusted. In scientific research, the method of critical analysis of scientific and methodological literature, practical experience, as required by the level of methodology and techniques of research is often used.

In the same scientific field there can be several methods (sets of methods), which are constantly being improved during scientific work. The most complicated is the technique of experimental research, both laboratory and field.
In different scientific fields, methods are used that coincide by name, for example, questioning, testing, scaling, but the goals and methods of their implementation are different.

The philosophical (fundamental) methodology is the higher level of the methodology of science, which determines the general stratum of the principles of knowledge of the peculiarities of phenomena, processes, spheres of activity. The development of the methodology is one of the sides of the development of cognition in general. Initially, the methodology was based on knowledge that dictated geometry as a science, which contained normative guidance for studying the real world. Then the methodology appeared as a set of rules for studying the universe and went into the sphere of philosophy. Plato and Aristotle considered the methodology as a logical universal system, a means of true knowledge [7]. Different approaches and methodologies in scientific research have been found to be sufficiently reflected in modern scientific literature.

Methodological function allows finding out the specifics of different levels of generalizations in the spheres of general scientific and special-scientific knowledge, defines the nature of the relationship of general and special historical theories, fundamental and applied research in various fields of knowledge. In science, there are three types of methods: 1) philosophical (basic); 2) general science; 3) special (specifically scientific) [8].

The philosophical (basic) methods include philosophical substantiation: empirical and theoretical, observation and experiment, selection and generalization, abstraction and concretization, analysis and synthesis, induction and deduction, formalization and actualization, historical and logical, reflective and axiomatica1 and a number others. These methods equally provide the productivity of research both in philosophy and in the field of other sciences: precise, natural, technical, and humanitarian. These methods are fundamental approaches to research in any field of knowledge. In accordance with the peculiarities of the problem and the content of the tasks, the choice of basic methods and their modifications in the course of one or another, including management research is carried out. In the context of culturological study, for example, in management, these methods are used in accordance with the objectives of the study, and, as a rule, the initial phase of the study involves the collection of 
empirical data, their generalization; however, another option based on philosophical reflection with the use of a logical or historical method in understanding the phenomenon of governance is possible. Undoubtedly, scientific research should use such methods as analysis and synthesis, induction and deduction, abstraction and updating. All basic methods equally provide the fundamental research, serve as an effective tool for all sciences, regardless of the fact that in the space of which subject areas they find their application. However, not only philosophical (basic) methods provide the emergence of new knowledge about the subject of research, but to a lesser extent, this is promoted by general scientific methods widely used in practice: descriptive, comparative, comparative-historical, which provides a comparison of processes, but not states, structural , typological, structuraltypological, systemic, modeling, reconstructive, genetic [9].

General scientific methods are a special group of scientific research technologies. They are developed and formed in social sciences and behavioral sciences and can be involved in other sciences. However, in the conditions of attraction, the rules of their application are adjusted according to the specifics of scientific discipline. The main difference between the general scientific methods from the philosophical (basic) is that the general scientific methods are more specific, more capable of taking into account the specifics of the subject. General scientific methods provide a more detailed analysis of problems, examine the subject of research from different sides and study newer data due to their perception in new perspectives and in new aspects. Today, the general scientific methods of research occupy a dominant position in social-humanitarian and behavioral sciences, and in recent years they will determine its meaningful development. However, the effectiveness of their use depends directly on how well the general scientific methods have been adjusted in line with the specifics of these sciences [10]

On the basis of general scientific methods, special (concrete-scientific) methods are gradually formed, which, as a rule, are used mainly only within a certain domain of knowledge. Methods developed directly in the subject field of social humanitarian and behavioral sciences are as follows: 1) methods of space reconstruction; 2) method of modeling administrative objects; 3) socio-cultural and historical-genetic method; 4) the method of mosaic reconstruction; 5) method of sociocultural observations; 6) the method of sociopsychological and socio-cultural inversions, etc. Special methods are limited by the feature of a particular subject of study, in this case, the object and subject of their study. General scientific methodology is used in the overwhelming majority of social humanitarian and behavioral sciences, since any scientific discovery has not only substantive but also methodological content, entails a critical review of the conceptual apparatus adopted, the factors, preconditions and approaches to the interpretation of the material being studied.

Approaches. In our opinion, it is necessary to distinguish the concept of "approach" and "method". An approach to research of anything characterizes the one from which the parties should be understood as the object of research. However, some approaches may simultaneously appear as methods. So, if the phenomenon of management to consider first of all as a system, then one of the methods of its study may be systemic.

The cognitive approach is associated with the general philosophical theory of cognition and is the methodological basis for many sciences; especially effective in studying the dynamics of science and its relationship with society, in justifying the leading importance of knowledge in the behavior of the individual. The terminological approach involves studying the history of terms and their notions, developing or refining the content and scope of concepts, establishing the relationship and subordination of concepts, their place in the conceptual apparatus of the theory, on the basis of which the study is based [11].

Historical approach allows studying the emergence, formation and development of processes and events in a chronological sequence in order to identify internal and external links, patterns and contradictions. In the framework of the historical approach in the method of historical-historical method - a set of cognitive means, procedures that can reveal the similarity and distinction between phenomena, genetic affinity is actively used.

Structural-functional approach consists in the allocation in the system objects of structural elements (components, subsystems) and determination of their role (functions) in the system. Elements and relationships between them create the structure of the system. Each

Methodology and organization of scientific researches in the field of social-humanitarian and behavioural sciences 
element performs its specific functions that "work" on system-wide functions. The structure characterizes the system in statics, functions - in dynamics. Between them there is certain dependence [12].

The system-activity approach has become widely distributed in modern scientific developments. It points to a certain component of human activity. Among the most important of its components: need - subject - object processes-conditions - result. This creates the opportunity to explore comfortably any sphere of human activity.

Relatively new is an informational approach, the essence of which is that, when studying any object, process or phenomenon in nature or society, the most characteristic information aspects of it are first of all revealed. At the heart of the information approach lays the principle of information, according to which: information is a universal, fundamental category; - practically all processes and phenomena have an informational basis; information is the bearer of the meaning of all processes occurring in nature and in society. The information approach has great heuristic opportunities in the study of the specificity of information flows (resources, sources, products and services) and the information needs of the subject domain through knowledge of laws, functions, attributes, properties, methods and means of information as content of messages or means of social communication (documentary, informational, cognitive).

Axiological (value) approach is based on the notion of value and gives an opportunity to find out the qualities and properties of objects, phenomena, processes that can meet the needs of an individual and a certain society. The essence of system approach lies in the complex study of large and complex objects (systems), the study of them as a whole with the consistent functioning of all parts. According to the system approach, the system is integrity, which is a unity of legally located and interconnected parts. The main features of the system are: 1) the presence of the simplest units - the elements that make it up; 2) the presence of subsystems - the results of the interaction of elements; 3 ) the presence of components - the results of the interaction of subsystems, which can be considered in relative isolation, outside the connection with other processes and phenomena; 4) the existence of the internal structure of the links between these components, as well as their subsystems; 5) communication with other systems of the environment. Simulation is essential for studying the internal and external connections of the object of study. It helps to study those processes and phenomena that are not subject to direct study. The simulation method has proven itself as an effective means of identifying essential features of phenomena and processes using a model (conceptual, verbal, mathematical, graphical and physical, etc.). Under the model the imaginary or material system is understood, which reflects or reproduces the object of research, can replace it so that its study gives new information about this object. The simulation method has the following structure: a) statement of the task; b) the definition of an analogue; c) creating or selecting a model; d) development of the structure; e) research of the model; g) transfer of knowledge from model to original. Consequently, the methodology of research in social, humanitarian and behavioral sciences is a set of methods, techniques, research processes and the creation of a theory of science [13].

General and special methods of scientific knowledge and their use. The success of scientific research depends to a large extent on the ability of a scientist to choose the most effective methods of research, since they are an opportunity to achieve the goal. Methods of scientific knowledge are divided into general and special. Most social problems of specific sciences and even individual stages of their research require the use of special methods of solving. They have a specific character and are studied, developed and refined in specific, special sciences. They are never arbitrary, because they are determined by the nature of the object being studied. General methods of scientific knowledge, in contrast to the special, are used in the research process in various sciences. Levels of scientific research: empirical and theoretical. The empirical and theoretical levels of research, as a rule, include abstraction, analysis and synthesis, induction and deduction, modeling, etc [14].

Abstraction has a universal character in mental activity, since each step of thought is connected precisely with this process or using its results. The content of this method consists in the apparent departure from the insignificant properties, relationships, relations of objects and at the same time, the fixation of one or several important features that are of particular interest to the researcher. The process of abstraction in the system of logical thinking is closely linked 
with other methods of research and, first of all, analysis and synthesis [15].

Analysis is a method of cognition that allows you to divide a subject into parts. Synthesis, on the contrary, is a consequence of the connection of individual parts or the feature of an object into a single whole. Analysis and synthesis are interrelated; they represent a unity of opposites. Depending on the level of knowledge of the object and the depth of penetration into its essence, an analysis and synthesis of various kinds are used. Direct, or empirical, analysis and synthesis are used at the stage of surface acquaintance with the object. In this case, the allocation of individual parts of the object, the detection of its properties, carried out the simplest measurements, fixing the direct data, lying on the surface. This type of analysis and synthesis makes it possible to know the phenomenon, but for penetration into its essence, it is insufficient. Reverse, or elementary theoretical, analysis and synthesis are widely used to study the essence of the phenomenon under study. Here the operations of analysis and synthesis are based on some theoretical considerations, that is, assumptions and causal relationships of various phenomena. The deepest penetration into the essence of the object is the possibility of structural and genetic analysis and synthesis. At the same time one can profoundly study causal relationships. This type of analysis and synthesis requires the allocation of such complex elements, such chains, which are central, main, affecting all other aspects of the object [16].

The methodology of the study should include the method of ascending from abstract to concrete, consisting in the general form of the movement of scientific knowledge, the law of reflection of reality and thinking. The idealization method is the designing of objects that are not in reality or which are practically impossible to implement. The purpose of idealization: to deprive the real objects of some inherent properties and to assign these objects with certain unrealistic and hypothetical properties.

Formalization is a method of studying various objects by displaying their structure in a sign form with the help of artificial languages, for example, the language of mathematics.

The advantages of formalization: ensuring the general approach to problem solving; the creation of symbols provides a concise and precise fixation of values; unambiguousness of symbolism (in order to avoid polysemy of ordinary language); the formation of sign models of objects and their replacement by the study of real things and processes [17].

Axiomatic method is a method of constructing a scientific theory, under which some statements are accepted without proof, and other knowledge is extracted from them in accordance with certain logical rules. Consequently, the methods of scientific research provide an opportunity to penetrate more deeply into the essence of the object of research, conduct a structural and genetic analysis, to deepen the study of causal relationships.

Approaches to the analysis of problems of social and humanitarian and behavioral sciences

The approach sets the direction, and cognitive techniques and means form its semantic nodes. Different approaches in scientific knowledge may be modified, specified and specialized through the operation of the principles and procedures of the method. The scope of methodological influence of the cognitive approach to the problems of sociohumanitarian and behavioral sciences of society as a result of this process is specified, and the approach itself acquires proper content and structural design. The approach sets the direction, cognitive techniques and means form its semantic nodes. Those or other approaches in scientific knowledge may be modified, specified and specialized through the operation of the principles and procedures of the method. The scope of the methodological influence of the cognitive approach to modern society is specified, and the approach itself acquires proper content and structural design.

The use of the cognitive approach opens up additional opportunities for finding out the dynamics of modern society. A cognitive approach should be a compulsory tool in the study of objective and subjective factors of the development of contemporary society, influencing the dynamics of the development of modern society, accelerating and stimulating the deployment of this process. The approach serves as the cornerstones of peculiar cognitive series, initiated by the relevant categories. For example, the category "historical in the development of modern societies" begins the cognitive series: the historical (the idea of historical) - the principle of historicism - the historical approach - the system of historical knowledge - the historical method (methodology). 
Anthropological approach is to identify the humanistic and universal humanities and behavioral sciences, representing the formation of such an ethos, which promotes the actualization of humanistic conditions for the realization of social humanitarian and behavioral sciences in which human development can be organically incorporated into the system of economic activity. It is an anthropological approach to human capital that involves the process of revealing the human dimension of all spheres of life, filling all social and economic processes with anthropological content. From this point of view, one can note the system of harmony: the inner world of man and the relationship of person and society, society and nation, nation and man, state and man. The anthropological and humanistic dimension of social, humanitarian and behavioral sciences should verify the "strength" of the state and its compliance with the parameters of civilization development of the nation and man. In the context of the culturological approach, the concept of social humanities and behavioral sciences is the cornerstone of the cultural formation of a nation in the context of the modernization of Ukrainian society. The culture of investing in a person is the use of knowledge, skills, habits, inclinations, ideas, values, investment experience; the role of investment values - in advocating the equality of opportunities of every person, the development of such models and mechanisms of state regulation, which would help to overcome the most dangerous for society destructive consequences of the transformation of intellectual relations (lack of education financing, science, etc.) [18].

The civilizational approach to socialhumanitarian and behavioral sciences proceeds from the necessity of defining civilization processes as a measure of civilization. In today's society, the importance of the foundations of intellectualized society, which contributes to the formation of universal human culture, is increasing. In modern conditions, there is a growing homogenization of economic, social and political forms that are combined with cultural diversity. In the context of a civilization approach, a methodological culture, consisting of many discrete structural elements, is established: the first is oriented towards the idea of a cultural way of life, based on the investment culture; the second - includes in the concept of culture - investment being, which is an innovative approach.
A system approach is an approach in which all social connections and mediations, elements and constituents of society, state and management, functions and problems of investment realization are considered as an interconnected whole. The system approach can be reduced to the following: when determining the social formation of investment activity as a system, an analysis of its elements is considered taking into account its place in general; the study of public investment education as a system is inseparable from the study of its interconnections with the external environment, since the object of investment is studied as a subsystem of a larger system, formed by the association of the object of investment with the environment. Between the components of social humanitarian and behavioral sciences there is a relationship of interdependence and freedom, which is expressed in the fact that the modification or modulation of one of these components (elements) predetermine certain changes of all others; in the investment system one can distinguish the regular type of connection that forms its structure, which, in turn, ensures the stability of the system and changes which lead to a radical transformation of it. The system approach to the analysis of problems of social, humanitarian and behavioral sciences is aimed at the analysis of any part of being with the connections of the environment; It is expedient to introduce a hierarchy of components (subsystems) and their ranking; analysis of the system and as a whole, and as a set of constituents; system analysis as dominant and subsystem as independent components; taking into account uncertainties and randomness in the socio-economic system; identification of the laws of the association of parts in the whole, laws that determine the nature of the structure, functioning and connection with the conditions and environment of functioning, boundary characteristics of the systems.

The institutional approach to the analysis of problems of social, humanitarian and behavioral sciences makes it possible to analyze social processes as a complex economic-social-cultural institution, through which the management of the development of human capital is carried out. From the standpoint of the institutional approach, human capital is a multidimensional vector category with a definite direction of development and with its inherent degree of influence and communication in the organization. Market factors are important for the formation and development of human 
capital, because the market through the price mechanism as a flexible signaling system and has the ability to minimize the effects of factors of uncertainty and risk. One of the institutions that reduce the uncertainty in these processes is the labor market, since under today's conditions an investor has a great deal of freedom in choosing an object and a subject of investment activity. Within the framework of the social and communicative approach to social humanities and behavioral sciences, it is necessary to analyze the processes of formation of a civilized state policy and the interconnection of all components of activity. A political and cultural approach will allow us to determine why institutes of the same form do not operate in different countries or because of which reasons certain institutions are capable of being in some countries and completely unacceptable in others.

A comprehensive approach to social, humanitarian and behavioral sciences involves taking into account all aspects, features and factors that directly or indirectly influence the resolution of human development optimization problems through civilized activities.

According to the systematic method, the problems of social humanitarian and behavioral sciences are considered in interconnection and interdependence, since a person is a complex system that allows to determine its structure, interrelations of elements, functions and their role in a changing and contradictory globalized world. It is thanks to this method that human activity appears to be an open and unbalanced system that orientates the scientist to study the complex of back relations between the nation, dissipative structures, nonlinearity, and others like that. Using the system method allows you to select a number of subsystems (lower-level systems) that are studied autonomously, taking into account the further alignment of the objectives of each subsystem with the overall purpose of the systems. The development of human capital, along with other elements, forms the structure of the system and determines the prospects for its development, realizing the principles of the man-centered dimension of human existence. The humanistic method for the analysis of social humanities and behavioral sciences is one of the fundamental principles in the methodology of scientific knowledge. At the theoretical level analysis of research methodology includes social humanism: the ratio of the human being as "essential matter" economic activity centered on human development "as the measure of all things"; the assertion of humanistic activity as an "organon" of the transformation of reality on the reasonable principles of the implementation of a set of economic and social values, needs, interests, individually distinct goals. The humanistic dimension of human activity - is the ideal society in which human development takes its existential value, considered as the realization of humanitarian activities in the light and create familiar modalities for amateur man in need of a radical change of state functions and ensure the efficiency of investment. Substance base of joint activity manifests itself in the existential of economic, political, social, spiritual values, reveals the problems of the dynamics of human development. Substation in humanistic activity is manifested in its stability in the norms, principles, forms, methods by which each nation confirmed in its national model of economic development and respect for human capital.

The axiological approach to the analysis of social, humanitarian and behavioral sciences is a basis that contributes to explaining the values of social life and overcoming the imperfection of the system. The axiological approach is manifested through the characterization of investment in human capital as values cultivated as a civilization phenomenon. Valuable definition of investment in human capital is disclosed through the value-practical orientation of both an individual and the state; at rationalizing the humanistic values of investment prospects being through investment reflection of events as "being - in - values" (economic, political and social) in their national diversity. The axiological approach to the culture of investment activity is to translate into it civilized values that act as an axiological factor in the choice of needs, interests, experiences, goals, plans, ways, implementations, outcomes of activities and the conditions under which they are implemented. A harmonious combination of economic and spiritual values forms a civilizational relationship, and the disharmony of axiological and economic factors distorts the culture of investment activity.

The synergetic method for the analysis of social, humanitarian and behavioral sciences makes it possible to define them as a complex, nonlinear, non-subordinated system, the further development of which cannot be uniquely determined. The synergetic method is reflected in the concepts: development; self development; self-organization; entropy; nonlinearity. On the

Methodology and organization of scientific researches in the field of social-humanitarian and behavioural sciences 
basis of the synergetic paradigm, activity appears as a unique process of self-organization of society, economy, politics, social and spiritual sphere; It is considered as a complex system, since it contains fundamentally different levels macro, micro and mega level. The fact that the micro level appears as a disorderly set of purely chaotic actions in social processes, at the macro level crystallizes into a certain order and regularity.

The synergetic method helps to identify patterns of socio-humanitarian and behavioral sciences that are self-organizing, so the central issue of the synergistic method is the ratio of order and chaos in society. The essence of such a metamorphosis is connected with the search for tenseness, that is, such a state, when the transitions of the system from one state to another are improved. The synergetic method is regarded as the theory of the formation of new ways of development: the hierarchy, branching, and the formation of a new type of feedback, which together form the fact that in the theory of dissipative systems is called self-organization [18].

\section{Methods}

The program-target method of the analysis of social, humanitarian and behavioral sciences depends on the methods of organizing scientific research and their ordering; constituent systems of scientific researches; development of the process of goal-setting in state-management activities; complex social and managerial, organizational phenomena; relatively independent program-target subsystem of the organization of scientific research - fundamental and applied.

The system-structural method of the analysis of social, humanitarian and behavioral sciences allows us to explicate the essence of contemporary self-developing socium, has a definite structure, and is manifested in the form of concrete variants of a single invariant system. This method allows us to consider the mechanism of ensuring the effective operation of the investment sphere, which, as a complex holistic system, which, in the final analysis, consists of simple elements that are selforganized. The system-structural approach allows us to consider the investment sphere as the functioning of numerical structures and substructures, which can be interpreted as its levels and forms in the context of their structures.

The systematic- structural method of analyzing social humanitarian and behavioral sciences includes a certain circle of theoretical and conceptual positions related to the multilevel, complex structure of the investment sphere, which makes it possible to distinguish, for a deeper understanding of its essence, the stable relations between its constituent elements, which connects them into a single whole. The systematic-structural method is necessary in the study of the system of socio-economic, moralethical and ethno-cultural principles that contribute to the formation of national interests as sources of modern state-building. Specification of integrity is a structural analysis the study of internal connections between individual subsystems of investment activity, where the structure is a way of interconnection of its elements, the internal organization of the system, expresses its essence and develops the general economic laws for it.

The structural-functional method of social humanitarian and behavioral sciences is used to study the functional dependencies of elements of human capital, having a certain structure, corresponding functions, which consist of different elements; it focuses more on statics where there is no genetic aspect, which more expressed in the idea of stabilizing society.

In the context of the system-functional method, one can study the relationship between social, humanitarian and behavioral sciences between economic, political, social and cultural components, making human activity an integrated system in which each element meets the different needs of the nation. In the study of processes and phenomena of social-political processes and behavioral phenomena, one must adhere to the optimal combination of theoretical and empirical levels of cognition, their integration in order to obtain new knowledge about the essence and peculiarities of humanitarian knowledge; for solving problems of human capital development, specific methodological methods of research are used which can be applied at the cognitive knowledge of the subject's aspects of the object - political and economic processes that reflect the development of a person as a carrier of intellectual capital.

\section{Conclusions}

Thus, the foundation of the methodology of social, humanitarian and behavioral sciences determines the general strategy of knowledge (phenomena, processes, spheres of activity). General scientific and specific scientific methodologies cause a critical view of the conceptual apparatus, factors of preconditions 
and approaches to the interpretation of scientific material. Sometimes, the methods of social humanitarian and behavioral sciences are divided into groups according to their functional capabilities: staged, that is, associated with certain stages of research, and universal, which are used at all stages. The first group includes observation, an experiment, and the second one abstraction, generalization, deduction, induction, and others.

Distinguish methods of theoretical and empirical research. Such a distribution of methods is always conditional, since with the development of knowledge, one scientific method can move from one category to another.
Methodology - the doctrine of the system of scientific principles, forms and methods of research activities. Fundamental or philosophical methodology is based on generalizing philosophical positions that reflect the most essential properties of objective reality and consciousness, taking into account the experience gained in the process of cognitive activity. General scientific and specific scientific methodology of social humanitarian and behavioral sciences is a system of scientific principles that ensure the systematic orientation of scientific research and practical knowledge of an object.

\section{Список використаних джерел}

1. Білогур В. Є. Формування концепції цілісної особистості: теоретико-методологічні виміри // Гуманітарний вісник Запорізької державної інженерної академії. 2014. Випуск 59. С.192-203.

2. Воронкова В. Г. Формування синергетично-рефлексивної моделі самоуправлінського суспільства: цивілізаційний контекст // Гуманітарний вісник Запорізької державної інженерної академії. 2012. Вип. 49. C.17-28.

3. Voronkova Valentina, Maksimenyuk Marina, Nikitenko Vitalina. Humanistic management in the context of phylosofic anthropology: human dimension // Нова парадигма: Національний педагогічний університет імені МП Драгоманова, Нова парадигма, творче об'єднання. 2016.- Вип. 129. С.64-76.

4. Воронкова В. Г., Фурсін О. О., Сапа Н. В. Соціально-орієнтоване державне управління: монографія . Запоіржжя: РВВ ЗДІА, 2011. 256 с.

5. Воронкова В. Г. Місце і роль України в глобалізаційних процесах сучасності// Гуманітарний вісник Запорізької державної інженерної академії. 2009. Вип. 37. С.16-32.

6. Кивлюк О. П. Глобалізація та інформатизація освіти в предметному полі філософії освіти // Гуманітарний вісник Запорізької державної інженерної академії. 2014. Вип. 57. С.192-200.

7. Кравченко I. М. Аналіз категорії трудовий потенціал в контексті категорій робоча сила, людський потенціал, людський капітал та трудові ресурси // Гуманітарний вісник Запорізької державної інженерної академії. 2012. Вип. 51. С.124-131.

8. Максименюк М. Ю., Нікітенко В.О. Інформаційно-комунікативне суспільство як різновид складної соціальної системи і взаємодії // Гуманітарний вісник Запорізької державної інженерної академії: [зб.наук.пр.] Запоріжжя: Вид-во ЗДІА, 2016. Вип. 66. С. 266-278.

9. Нікітенко В. О. Сучасна геокультура як соціокультурний феномен // Гуманітарний вісник Запорізької державної інженерної академії, Вип.53. 2013. С. 261-270.

10. Nikitenko Vitalina. Cultural and social competence creation in the process of English language study: information society aspect // Humanitarian Bulletin of Zaporizhzhia State Engineering Academy. Issue. 2016. 251-257.

11. Олексенко Р. І. Вплив комунікацій на ціннісні орієнтири особистості / Р. І. Олексенко // Гуманітарний вісник Запорізької державної інженерної академії. 2015. Вип. 62. С. 65-73.

12. Олексенко Р. И. Философия образования как неотъемлемый фактор экономического развития общества // Социосфера. 2013. № 3. С. $19-26$

13. Синясва Л. В., Олексенко Р. І., Плаксіна І. М. Екологічні проблеми України та шляхи їх вирішення // Вісник Сумського національного аграрного університету. 2007. № 4. С.12- 15

14. Олексенко Р. І., Молодиченко В. В. Концептуальні пріоритети формування сучасної людини економічної // Гуманітарний вісник Запоірзької державної інженерної академії. 2017. № 70. С. 164 - 175.

15. Олексенко P.І. Перспективи й основні напрями розвитку сучасної економічної освіти // Гуманітарний вісник Державного вищого навчального закладу "Переяслав-Хмельницький державний педагогічний університет імені Г. С. Сковороди". Педагогіка. Психологія. Філософія. 2013. Вип. 28(1). С. 379-384

16. Пожуєв В. І. Осмислення місця і ролі інформації у сучасному суспільстві // Гуманітарний вісник Запорізької державної інженерної академії. Запоріжжя: Вид-во ЗДІА, 2010. Вип. 42. С. 4-13.

Methodology and organization of scientific researches in the field of social-humanitarian and behavioural sciences 
17. Пунченко О. П., Лазаревич А. А. Інформатизація як засіб репрезентації інформаційних ресурсів суспільства Гуманітарний вісник Запорізької державної інженерної академії: [зб.наук.пр.] Запоріжжя: Вид-во ЗДІА, 2015. Вип. 63. С. 21-30.

18. Утюж I. Г. Цивілізаційна парадигма освіти: теоретико-методолоігчний аспект // Гуманітарний вісник Запорізької державної інженерної академії: [зб.наук.пр.] Запоріжжя: Вид-во ЗДІА, 2009. Вип. 38. C. 60-66.

\section{REFERENCES}

1. Bìlogur, V. E. (2014). Formation of the concept of an integral personality: theoretical and methodological dimensions // Humanitarian Bulletin of Zaporizhzhia State Engineering Academy. Zaporozhie: publishing ZDIA.Issue 59. 192-203 [in Ukrainian].

2. Voronkova, V. G. (2012). Formation of synergistically-reflexively model samoupravlìnskogo society: the civilizational context // Humanitarian Bulletin of Zaporizhzhia State Engineering Academy. Zaporozhie: publishing ZDIA.Issue. 49. 17-28[in Ukrainian].

3. Voronkova, Valentina, Maksimenyuk Marina, Nikitenko Vitalina (2016). Humanistic management in the context of phylosofic anthropology: human dimension // A new paradigm: the national Drahomanov Pedagogical University, new paradigm, creative Union.Issue. 129. 64-76 [in Ukrainian].

4. Voronkova, V. G., Fursìn, O.O., Sapa, N.V. (2011). Socially-oriented State management: monograph. Zaporozhie: publishing ZDIA. $256 \mathrm{~s}$. [in Ukrainian].

5. Voronkova, V.G.(2009). Place and role of Ukraine in contemporary processes of globalization // Bulletin of Zaporizhzhia State Engineering Academy. 2009. Zaporozhie: publishing ZDIA. Issue. 37. 16-32 [in Ukrainian].

6. Kyvliuk, O. P. (2014). Globalization and Informatization of education in the subject field of the philosophy of education // Humanitarian Bulletin of Zaporizhzhia State Engineering Academy. Zaporozhie: publishing ZDIA. Issue. 57. 192-200 [in Ukrainian].

7. Kravchenko, I. M. (2012). Analysis of the category of employment potential in the context of categories of workforce, human potential, human capital and human resources // Humanitarian Bulletin of Zaporizhzhia State Engineering Academy. Zaporozhie: publishing ZDIA. Issue. 51. 124-131 [in Ukrainian].

8. Maksimenûk, M. Yu., Nikitenko, V. O. (2016). Informational and communicative society as a kind of complex social systems and interaction // Humanitarian Bulletin of Zaporizhzhia State Engineering Academy. Zaporozhie: publishing ZDIA. Issue. 66. 266-278 [in Ukrainian].

9. Nikitenko, V. O. (2013). Modern geokultura as a sociocultural phenomenon // Humanitarian Bulletin of Zaporizhzhia State Engineering Academy. Issue 53. 261-270 [in Ukrainian].

10. Nikitenko, Vitalina (2016). Cultural and social competence creation in the process of English language study: information society aspect // Humanitarian Bulletin of Zaporizhzhia State Engineering Academy. Zaporozhie: publishing ZDIA. Issue. 251-257 [in Ukrainian].

11. Oleksenko, R. I. (2015). The impact of communications on the value guidance of personality // Humanitarian Bulletin of Zaporizhzhia State Engineering Academy. Zaporozhie: publishing ZDIA. Issue. 62. 65-73[in Ukrainian].

12. Oleksenko, R. I. (2013). Philosophy of education as a nevidêmnij factor in the economic development of the society // Sociosfera. № 3. S. 19-26 [in Ukrainian].

13. Sinâêva L.V., Oleksenko R. I., Plaksìna I. M. (2007). Environmental problems and their solutions // Bulletin of the Sumy national agricultural University. № 4. 12-15 [in Ukrainian].

14. Oleksenko, R. I., Molodičenko, V.V. (2017). Conceptual priorities formation of the modern human economic // Humanitarian Bulletin of Zaporizhzhia State Engineering Academy. Zaporozhie: publishing ZDIA.Issue 70. 164-175 [in Ukrainian].

15. Oleksenko, R. I. (2013). Prospects and main directions of the development of modern economic // Humanitarian bulletin State higher educational establishment "The Pereyaslav-Khmelnytsky State Pedagogical University after G.S.Skovoroda." Pedagogy. Psychology. Philosophy. Issue. 28 (1). 379-384 [in Ukrainian].

16. Požuêv, V. I. (2010). Understanding the place and role of information in modern ssupìlstvì//Humanitarian Bulletin of Zaporizhzhia State Engineering Academy. Zaporozhie: publishing ZDIA.Issue. 42. 4-13 [in Ukrainian].

17. Punčenko, A. P., Lazarevich, A. A. (2015). Informatization as a means of disseminating the information resources of the society of Humanities Bulletin of Zaporizhzhia State Engineering Academy. Zaporozhie: publishing ZDIA. Issue. 63. S. 21-30 [in Ukrainian].

18. Utûž, I. G. (2009). Civììzacìjna paradigm of education: theoretical-metodoloìgčnij facet//Humanitarian Bulletin of Zaporizhzhya State Engineering Academy. Zaporozhie: publishing ZDIA. Issue. 38. 60-66 [in Ukrainian].

Бойко О. В. - Запорізька державна інженерна академія (Запоріжжя, Україна)

E-mail: lvbojko@yahoo.com, ORCID 0000-0003-0719-8921

(C) Bojko Elena,Voronkova Valentyna, Nikitenko Vitalina, 2018 
Воронкова В. Г. - Запорізька державна інженерна академія (Запоріжжя, Україна)

E-mail: valentina-voronkova236@gmail.com, ORCID: 0000-0003-4361-1701

Нікітенко В.О. - Запорізька державна інженерна академія (Запоріжжя, Україна)

E-mail: vitalina2006@ukr.net, ORCID: 0000-0001-9588-7836

\section{МЕТОДОЛОГІЯ ТА ОРГАНІЗАЦІЯ НАУКОВИХ ДОСЛІДЖЕНЬ В ГАЛУЗІ СОЦІАЛЬНО- ГУМАНІТАРНИХ ТА ПОВЕДІНКОВИХ НАУК}

Анотація. Актуальність дослідження в тому, що сучасний соціально-економічний розвиток характеризується постійним оновленням системи наукових знань, інтенсивним зростанням кількості та складності інформації. В цих умовах перед вищою школою постає завдання підготовки високоваліфікованих фахівців, які на якісно новій теоретико-методологічній базі здатні глибоко i системно аналізувати складності сучасного світу, приймати оптимальні рішення для суспільства в цілому та економіки, зокрема. Центральною проблемою $є$ дослідження методів і підходів наукового пізнання, завдяки яким можна глибоко проникнути в сутність досліджуваних явищ і процесів об'єктивної дійсності. Задачі дослідження - аналіз сукупності методів і підходів, що в своїй сукупності складають методологію та організацію наукових досліджень і $є$ корисними для соціально-гуманітарних та поведінкових наук. Методологія (гр. теthodos - спосіб, метод i logos - наука, знання) - вчення про правила мислення при створенні теорії науки. Методологію розглядають як вчення про науковий метод пізнання або як систему наукових принципів, на основі яких базується дослідження і здійснюється вибір сукупності пізнавальних засобів, методів, прийомів дослідження. Результат дослідження. Філософська методологія виконує два типи функцій: 1) виявляє смисл наукової діяльності та її взаємозв'язки з іншими сферами діяльності, тобто розглядає науку стосовно практики, суспільства, культури людини; 2) вирішує завдання вдосконалення, оптимізації наукової діяльності, виходячи за межі філософії, хоча й спирається на розроблені нею світоглядні й загальнометодологічні орієнтири. Методологія - це концептуальний виклад мети, змісту, методів дослідження, які забезпечують отримання максимально об'єктивної, точної, систематизованої інформації про процеси та явища, що досліджуються. Висновки. Методологія та організація наукових досліджень вивчає закономірності функціонування та розвитку науки, структуру і динаміку наукового пізнання, глибокого проникнення в сутність досліджуваних явищ та процесів.

Ключові слова: метод, методологія, підхід, технологія, методика, наукове пізнання, філософська методологія.

Бойко Е. В. - Запорожская государственная инженерная академия (Запорожье, Украина) Е-mail: lvbojko@yahoo.com, ORCID 0000-0003-0719-8921

Воронкова В. Г. - Запорожская государственная инженерная академия (Запорожье, Украина) E-mail: valentina-voronkova236@gmail.com, ORCID: 0000-0003-4361-1701

Никитенко В. А. - Запорожская государственная инженерная академия (Запорожье, Украина) Еmail: vitalina2006@ukr.net, ORCID: 0000-0001-9588-7836

\section{МЕТОДОЛОГИЯ И ОРГАНИЗАЦИЯ НАУЧНЫХ ИССЛЕДОВАНИЙ В СФЕРЕ СОЦИАЛЬНО-ГУМАНИТАРНЫХ И ПОВЕДЕНЧЕСКИХ НАУК}

Аннотация. Актуальность исследования в том, что современное социально-экономическое развитие характеризуется постоянным оновлением системы научных знаний, интенсивным увеличением количества и сложности информации. В этих условиях перед высшей школой стоит задача подготовки высококвалифицированных специалистов, которые на качественно новой теоретико-методологической основе способны глубоко и системно анализировать сложности современного мира, принимать оптимальные решения для общества в целом и экономики, в частности. Центральной проблемой есть исследование методов и подходов научного познания, благодаря которым можно глубоко проникнуть в сущность исследуемых явлений и процессов объективной действительности. Задачи исследования анализ совокупности методов и подходов, которые в своей совокупности составляют методологию и организацию научных исследований и есть полезными для социально-гуманитарных и поведенческих наук. Методология - (гр. теthodos - способ, метод и $\operatorname{logos}$ - наука, знание) - учение о правилах мышления при создании теории науки. Методологию рассматривают как учение о научном методе познания или как систему научных принципов, на основе которых базируется исследование и осуществляется выбор совокупности познавательных средств, методов, прийомо исследования. Результат исследования. Философская методология выполняет два типа функций: 1) выявляет смысл научной деятельности и их взаимосвязи с другими сферами деятельности, то есть рассматривает науку применительно практики, общества, культуры человека; 2) решает задачи усовершенствования, оптимизации научной деятельности, выходя за пределы философии, хотя и опирается на разработанные ею мировоззренческие и общеметодологические ориентиры. Методология - это концептуальное изложение цели, содержания, методов исследования, которые обеспечивают получение максимально объективной, точной,

Methodology and organization of scientific researches in the field of social-humanitarian and behavioural sciences 
систематизированной информации о процессах и явлениях, колторые исследуются. Выводы. Методология и организация научных исследований изучает закономерности функционирования и развития науки, структуру и динамику научного познания, глубокого проникновения в сущность исследуемых явлений и процессов.

Ключевые слова: метод, методология, подход, технология, методика, научное познание, философская методология.

Стаття рекомендована до публікаиії д.філософ.н., проф. Білогур В.С. (Мелітополь, Украӥна) Надійшла до редколегї: 15.03 .18 р. Прийнята до друку: 20.03.18 p

Бойко Олена Володимирівна - доктор економічних наук, доцент, професор кафедри менеджменту ВАорганізацій та управління проектами, Запорізька державна інженерна академія (Запоріжжя, Україна)

E-mail: lvbojko@yahoo.com, ORCID 0000-0003-0719-8921

Воронкова Валентина Григорівна, доктор філософських наук, професор, завідувач кафедри менеджменту організацій та управління проектами, Запорізька державна інженерна академія (Запоріжжя, Україна), вул Незалежної України, 58-А, кв 29, 69037 Запоріжжя, Україна.

E-mail: valentinavoronkova236@gmail.com ORCID: 0000-0003-4361-1701

Нікітенко Віталіна Олександрівна - кандидат філософських наук, доцент кафедри філософії та суспільних наук, Запорізька державна інженерна академія (Запоріжжя, Україна), проспект Соборний, 226, ЗДІА 69006 Запоріжжя, Україна.

E-mail: vitalina2006@ukr.net ORCID: 0000-0001-9588-7836

(C) Bojko Elena,Voronkova Valentyna, Nikitenko Vitalina, 2018 